\title{
The Rhetoric and Reality of Localisation: Refugee-Led Organisations in Humanitarian Governance
}

Kate Pincock, Alexander Betts, and Evan Easton-Calabria

\begin{abstract}
When refugees flee war and persecution, protection and assistance are usually provided by United Nations organisations and their NGO implementing partners. In parallel is a largely neglected story: refugees themselves frequently mobilise to provide protection and assistance to other refugees. At a global level, there has been a shift in the rhetoric of international policy makers towards 'localisation' and the inclusion of refugees, which potentially provides an opportunity to engage with refugee-led community organizations (RLOs). However, RLOs rarely receive access to international recognition or funding despite often being regarded by refugees as an important source of assistance.

In this article, we draw upon ethnographic research on the interactions between international institutions and refugee-led organisations in Kampala, Uganda, to explore how 'localisation' unfolds in practice within humanitarian governance. In the absence of a clear policy framework for localisation at the global level, national level representatives have considerable discretion in whether and how they partner with RLOs, leading largely to their exclusion - and the development of alternative strategies by RLOs to find support. We suggest that an effective localisation agenda will require much more attention to the role of power and interests at the local level itself if RLOs are to be engaged as meaningful actors in humanitarian assistance.
\end{abstract}

Word Count: 9,259 


\section{Introduction}

At the global level, there has been growing recognition within the UN system of the role played by local actors, leading to a concern to 'localise' funding and activities, in policy fields from development to humanitarianism. An academic literature on 'localisation' has emerged seeking to explain how international norms and organisations interact with local norms and actors (Acharya 2004, 2009; Cloward 2014, 2016; Betts and Orchard 2014). This work has echoes of critical development studies' concern with how the culture and practices of international organisations interact with local practices (Ferguson 1990; Scott 1998; Escobar 2011), as well as longstanding debates on participatory approaches to development (Chambers 1986, 1997; Cleaver 1999).

In practice, one recent 'localisation turn' has been within humanitarian policy. The World Humanitarian Summit (WHS) in 2016 placed a strong emphasis on 'localisation', recognising and supporting 'crisis affected people' as important first responders to crisis. Localisation, in the context of the World Humanitarian Summit, was framed as a means to increase the legitimacy and effectiveness of humanitarian assistance (Van Brabant and Patel 2017). Proponents of localisation pointed to the efficiency gains of bypassing an 'oligopoly' of slow, bureaucratic, and expensive intermediary organisations (Parker 2016; Grand Bargain 2016; Bennett 2016), as well as the normative importance of overcoming power asymmetries inherent to 'top-down' global responses (Van Brabant and Patel 2017). The WHS's Grand Bargain (2016) committed states to channel $25 \%$ of overall humanitarian funding to 'national and local actors', but with significant ambiguity over the definition of such actors.

But how does localisation work in practice? In order to explore this, we look empirically at one aspect of humanitarian localisation: the role of refugee-led organisations within global refugee governance. Conventionally, refugee assistance is provided by international donor governments funding the UN Refugee Agency (UNHCR) which in turn delegates assistance to international NGO 'implementing partners' in specialist areas from shelter to water and sanitation. The dominant humanitarian model is premised upon a clearly defined providerbeneficiary relationship. In parallel, however, refugees themselves frequently mobilise to create community-based organisations or informal networks that serve as alternative providers of protection and assistance to other refugees. This role is not only in advanced industrialised countries (Phillimore 2012; Griffiths et al 2006; Bloch 2008; Zetter and Pearl 2000 ) but also the low and middle income countries that host $85 \%$ of the world's refugees (Fiddian-Qasmiyeh 2015; Betts and Jones 2016; Bradley et al. 2019).

Within global-level policy debates, there is rhetorical recognition of the potentially important role of refugee-led organisations (RLOs). UNHCR's Community-Based Protection Policy (2013) which provides an aspirational framework notes that "every community that faces threats engages in forms of individual or collective self-protection" and that "it is almost always better to work through existing institutions and programmes rather than establish new or parallel ones". UNHCR's (2018) Global Compact on Refugees, highlights the importance of a 'multistakeholder and partnership approach' and mentions 'local actors'. Meanwhile, the inaugural UN Global Refugee Forum in 2019 invited participation by a range of community-based 
organisations (CBOs), including refugee-led organisations, such as the Global Refugee-Led Network, a coalition of local refugee leaders and refugee-led organisations. Furthermore, some international NGOs working with refugees, such as St Andrew's Refugee Services, Oxfam, HIAS, and the Finnish Refugee Council have begun to collaborate proactively with RLOs on the ground (Pincock et al 2020).

However, despite rhetorical reorientation at the global level, there is no clear UNHCR policy framework on how the organisation or its implementing partners should work with RLOs in practice. For example, the Global Compact is not explicit about what role could be envisaged for refugee-led organisations. In the absence of clear guidance, there is significant variation in practice. The result is that RLOs generally received little recognition or funding, despite representing a significant source of social protection within refugee-hosting camps and cities.

The COVID-19 pandemic has made the need to focus on localisation even more timely and important. As international agencies have been forced to withdraw or significantly reduce their operations, RLOs have by default found themselves at the front line of the response, delivering food assistance, disseminating information, and supporting community-level public health initiatives in both camps and cities. International actors have begun to explore new mechanisms to support remote and participatory humanitarian aid delivery. However, donor governments have remained reluctant to directly finance RLOs, partly due to concerns relating to risk and accountability (Betts, Easton-Calabria, and Pincock 2020).

In this article, we use the case of RLOs to explore how localisation works in practice. We focus on the interaction between RLOs and international humanitarian actors. In particular, we explore how UN agencies and international NGOs engage with, bypass, and selectively include RLOs, and what implications this has for the emergence and form of RLO-provided social protection activities. We do so by focusing on the case study of RLOs in Kampala, Uganda, which is home to around 80,000 refugees (UNHCR 2020). INGOs and UN bodies are often reluctant to partner with small local entities due to a lack of formal registration yet in Kampala RLOs are able to legally register as NGOs, and are still routinely bypassed by international actors. Through our research, we documented over 30 registered RLOs in the city delivering substantive social protection activities to the community; however none are recognised as implementing partners of UNHCR and most function without international recognition or funding.

We show that, in the absence of a clear policy framework at the global level, formal humanitarian organisations have discretion in whether and how they partner with RLOs. As a result, RLOs are largely bypassed or instrumentalised by international actors. Nevertheless, we show that in the case of Kampala a small group of RLOs have gained status and legitimacy as humanitarian actors within the communities they serve in the city despite a lack of formal recognition or funding by international humanitarian and development actors. They have done so by creating their own transnational networks that bypass formal humanitarian governance. Put simply, RLOs that succeed in growing and establishing themselves as important providers of social protection and assistance do so in spite of, rather than because of, the formal humanitarian system. We suggest that these findings have wider implications 
for how we understand the political economy of localisation in relation to humanitarianism and development.

\section{Literature and Contribution}

We define localisation as the delegation of governance authority to communities immediately affected by policy choices within a particular policy field. Within humanitarian policy, the definition is contested, and no single definition has been agreed (Grand Bargain 2016; Van Brabant and Patel 2017). Nevertheless, one organisation posited that it involves "a process of recognising, respecting and strengthening the independence, of leadership and decision making by national actors in humanitarian action, in order to better address the needs of affected populations" (IFRC 2018). Meanwhile, it is informally understood by many humanitarian commentators to imply the empowerment of 'crisis-affected communities' and 'first responders', and to entail striking an appropriate and complementary balance between the role of international and local actors; in the words of the UN Secretary-General 'as local as possible, as international as necessary' (Barbelet 2018).

Some work on the politics of localisation has highlighted the ways international institutions adapt to norms and power structures within particular regions, countries and local contexts (Acharya 2004; Cloward 2014, 2016) and shown that the implementation of global norms and standards is mediated through national and local politics (Betts and Orchard 2014). Yet these approaches offer a top-down perspective on the translation of institutional practices at a local level that does not fit with the recognition of refugee agency that the wider ethnographic literature demands. They also treat the 'local' as a space in opposition to the 'global' from a Eurocentric vantage point - potentially obscuring the ways that the 'local' itself is heterogenous and a site of contestation and power struggles (MacGinty 2015; MacGinty and Richmond 2013; Autesserre 2010). The risk is that such a dualistic approach may sideline the complex political economy that plays out at the local level.

'Critical localism' emphasizes ways that processes of authority and power unfold within local contexts, as well as are shaped by interactions with international actors and stakeholders (Roepstorff 2020). It can be used to interrogate the ways that the 'local' can be used as a legitimation strategy by international actors - and by local actors themselves as a resource for accessing funding (Roepstorff 2020). Challenging the 'rediscovery' of the local in peacebuilding as a solution to what they describe as deliberate 'de-localising' under colonialism and development, MacGinty (2015) argues that the 'local' must be decoupled from its twinning with the 'global' and treated as an independent geographical space, in order to recognise the contested and shifting nature of the 'local' as a space of human agency and activity which changes over time. Roepstorff (2020) points out that without challenging these underlying assumptions, a move towards 'localisation' is likely to perpetuate exclusionary practices within the humanitarian sector.

Whilst a more critical approach to localisation debates has hitherto excluded refugees as humanitarian actors, there is a rich body of work which emphasizes the agency of refugees and the power dynamics of refugee governance. Contributions include ethnographic 
literature on refugees' agency (Harrell-Bond 1986; Chambers 1986; Hammond 2004; Kibreab 1987; Horst 2008; Grabska 2006). A growing strand of this work focuses on refugees' economic agency (Jacobsen 2005; Werker 2007; Betts et al 2016; Maystadt and Verwimp 2009; Ruiz and Vargas Silva 2015; Krause 2014; Carrier 2016) and their transnational political mobilisation (Mylonas 2017; Horst 2008; Salehyan 2010; Lischer 2005).

Meanwhile, within a European and North American context, there has been a growing body of literature on refugee community organisations, including those providing assistance to other refugees (Gold 1992; Zetter et al 2005; Phillimore 2012; Griffiths et al 2006; Bloch 2008; Zetter and Pearl 2000). Organised refugee-to-refugee support in the global South has also emerged as a research theme (Fiddian-Qasmiyeh 2015). Research has focused, for example, on how refugees engage in creating the conditions for durable solutions, particularly the political conditions to return home, through influencing authoritarian transition (Betts and Jones 2016), and peace-building (Milner 2009; Bradley et al. 2019; Horst 2019; Purkey 2019) within the country of origin.

Research has also been undertaken looking at the role of 'civilian self-protection', including by internally displaced populations, in the context of armed conflict (Baines and Paddon 2012; Suarez 2017; Kaplan 2013; Luft 2018; Jose and Medie 2015; Masullo et al. 2019; Sutton 2018; Jentzch 2018). This work has examined the range of strategies adopted by crisis affected communities when faced with armed conflict or mass atrocities, including through nonengagement (e.g. flight, seeking protection, or information sharing); non-violent engagement (e.g. protest, collaboration, or deception), or violent engagement (e.g. self-defense or joining militias or rebel groups) (Jose and Medie 2015). However, noticeably absent from this literature has been a focus on refugees as local actors in the provision of protection and assistance to other refugees within countries of asylum.

Furthermore, a notable gap exists in examining the interaction between international institutions and refugee-led organisational alternatives. Rather than merely describe the activities of refugee-led organisations, or make a normative case for greater localisation, there is a need to empirically examine localisation as an inherently contested process. By exploring the interaction between international institutions and refugee-led organisations, our aim is to critically understand the political economy of localisation.

\section{Materials and Methods}

Methodologically, we draw upon ethnographic research on the institutional context, refugees' activities, and formal humanitarian and development actors-RLO interaction in Kampala. Our principal ethnographic methods were semi-structured interviews, focus groups, and participant observation, with supplementary fieldwork conducted by all authors. We used 'snowballing' to gain access to RLOs and refugee-led networks, initially through existing contacts. In Kampala, we undertook repeated ethnographic interviews with twenty-five leaders of RLOs; attended around fifteen networking meetings run for and by refugee-led organisations; held two focus groups and a workshop to discuss and reflect on our findings; and spent hundreds of hours across 15 months of fieldwork observing the activities and 
programmes of RLOs in two sites in Uganda and in Kenya. This was complemented by interviews with UNHCR staff; staff in its sole implementing partner in Kampala, InterAid Uganda; and staff working for the Finnish Refugee Council, which had undertaken innovative capacity-building work with RLOs in previous years.

In order to avoid the pitfall of simply paying lip service to refugee agency, a key challenge of our fieldwork involved embedding a 'localised' ethos within our methodology and building collaborative relationships with refugee-led organisations. A small number of key nodal actors served as partners, helping us to navigate various communities and attain introductions. We chose to focus on Congolese, South Sudanese and Somali refugee-led social protection because these represent the greatest numbers of refugees in both Uganda and Kenya, and the larger project of which this paper is part sought to draw comparisons between these two countries' different institutional environments. Throughout the project we sent monthly updates to participants in Kampala about the project's progress, and at the end of fieldwork, refugees were involved in shaping our findings by offering feedback and sharing observations at a workshop held in Kampala to launch a formal organizational network for RLOs in the city. We remain committed to sustaining these relationships over time, aware of the challenges relating to the abrupt termination of relationships by researchers departing the field.

Data analysis was inductive and iterative, with the authors holding weekly meetings by Skype during fieldwork to discuss the trajectory of the research and identify questions that were emerging, to explore going forward. The first phase of fieldwork in Kampala was interspersed with fieldwork in Nakivale, a settlement in the south of Uganda, and followed with fieldwork in Kenya (Nairobi and Kakuma). Once fieldwork had been completed, the authors used the key questions that had guided the project to draw up tables of data including observations and quotes, which were used build a picture of the character of refugee-led social protection in Kampala. Based on the questions and which emerged from our analysis of refugees' own narratives, further interviews were then conducted with UNHCR and its implementing partner staff, helping us to identify gaps between 'top down' and 'bottom up' framings of refugee-led social protection.

Despite our best efforts, we recognize various limitations to the study. Our 'entry points' were through nodal actors with whom the research team had a pre-existing relationship, and whilst these individuals were of different nationalities and communities, as an approach this inevitably limited our pool of participants. We undertook interviews with people working for only one 'local' organization that was not run by refugees, InterAid, because of its monopoly status as a partner of UNHCR - but investigating the workings of other local community-based or national NGOs might have shed more light on whether the difficulties faced by small refugee CBOs might also affect small Ugandan CBOs. Finally, whilst in other sites we worked with peer researchers, with Kampala being our first field site we had not yet set up a process for recruiting and training collaborators during this phase of the fieldwork. Thus our findings reflect the insights of the authors of this paper rather than refugee researchers, albeit with feedback from refugees who have engaged with our work from the beginning.

\section{Refugee-Led Social Protection in Kampala}


In April 2017, an article in the Guardian newspaper asked: 'Is Uganda the world's best place for refugees?' (Rwakaringi 2017). It described the welcoming nature of Uganda's refugee policies, which offer refugees the right to work and freedom of movement. Under the government's Self-Reliance Strategy, refugees in Uganda's settlements are provided land to farm and basic material assistance. Yet in Kampala, direct formal assistance to refugees is virtually non-existent - a key point to note when thinking about where refugees turn for support. Indeed, when asked to whom they would turn for social protection in an emergency, nearly $90 \%$ of refugees in the city said they would turn to their own communities (Betts et al. 2019).

The explicit focus of UNHCR and the Government of Uganda services to refugees is 'protection': a category encompassing status determination, processing, documentation, and counselling. A host of international and national non-governmental organisations work as operational partners for UNHCR, with the shared objective of integrating refugees into Uganda's healthcare and education systems. The only Implementing Partner of UNHCR in Kampala is InterAid, a Ugandan NGO which since 1995 has delivered the Urban Refugee Programme under a tripartite agreement with UNHCR and the Office of the Prime Minister, which is responsible for refugee management on behalf of the government of Uganda. As in other places, the distinction between operational and implementing partner is a financial one; only implementing partners receive funding from UNHCR.

This paper focuses on what we term 'refugee-led social protection' in Kampala, Uganda - the provision of goods such as emergency assistance, education, and healthcare by refugees for refugees. Uganda's context in this regard is interesting as it affords refugees the right to work and the freedom of movement that are often denied elsewhere. Likely due in part to this, Kampala is home to nearly 80,000 refugees. Over the course of our research, we identified over 30 refugee-led organisations in the city, some with significant capacity. However, a gap remains in refugees' agency over the formal assistance they are provided despite the relative freedom they enjoy in other areas. Despite the existence of RLOs, and refugees' concerns over the quality of InterAid's work, RLOs are not funded through UNHCR or considered seriously as potential implementing partners. Indeed, most UNHCR staff in the city are largely unaware of their existence.

Yet beyond formal assistance institutions, a diverse landscape of RLOs has flourished in Kampala. These initiatives support refugees, and often Ugandans too, to build lives in the city in spite of the lack of support and assistance available to them. Filling the gap in services available from InterAid's Urban Refugee Programme and the limited alternative assistance offered by formal institutions in the city, refugees have set up numerous initiatives. These include language classes and financial literacy classes to promote integration with the host community; peace promotion projects to bring together young people from different ethnicities; and business training in areas such as hairdressing, tailoring and agriculture to help them thrive in Kampala. 
Figure 1 maps the main international humanitarian and development actors, national organisations, and refugee-led organisations we identified during our research in Kampala. The figure is not intended to be comprehensive but serves to illustrate the types of connections and partnerships that exist between formal international and national organisations and those led by refugees, and those that exist between the refugee-led groups. In particular, it shows the limited engagement between formal institutions and RLOs in their various forms. Most refugee-led organisations were not receiving assistance from UNHCR or its partner organisations in Kampala, and a significant number had managed instead to find alternative streams of funding.

[Insert Figure 1: Refugee-led, national, and international organisations in Kampala]

The figure offers an overview of the variety of organisational forms that refugee-led protection and assistance take across the main nationality groups in Kampala. For Somalis, the formal provision of social protection through the formation of disparate RLOs is not a priority; it is coordinated along hierarchical lines through a community umbrella organisation, the Somali Community Association (SCA). The SCA exists to ensure that those in need are assisted within the community, and regularly advocates to the Office of the Prime Minister (OPM) for the continued security of the Somali community as a whole. Its form is thus shaped through both Somali cultural norms around authority and leadership, and by the institutional structures it sees as most relevant; OPM does not expect to work through an RLO, and Somalis do not expect assistance from those who might be.

South Sudanese refugee leaders - often the heads of pre-existing organisations in South Sudan - sometimes explained that they chose to settle in Uganda due to its straightforward laws on grassroots organisations and relatively benign stance on refugees. Kampala is therefore something of a utilitarian destination for South Sudanese human rights defenders like Inter-Youth Africa, the Global Society Initiative for Peace and Democracy, and Africa Youth Action Network, which have fostered contact with formal humanitarian and development organisations who are interested in supporting the South Sudan peace process. However, South Sudanese refugees do not look to the government of Uganda for anything more than this; their sources of support remain transnational, namely formal humanitarian and development actors invested in South Sudan's future.

In contrast, formal social protection organisations proliferate among the Congolese community. The Refugee Led Organisations Network (RELON), a Kampala-based network of RLOs recently created by Congolese refugees, is illustrated in Figure 1 by a line around its nine member organisations. Congolese refugees are the most numerous nationality group in Kampala. Partly reflecting this, Congolese-led RLOs have proliferated, engaging in activities as diverse as providing business training, teaching English, and exerting political pressure on the formal refugee system in Kampala. The formal registration of groups of refugees as community-based organisations rather than just 'self-help groups' is very common among the Congolese community. 
As is clear from Figure 1, funding for RLOs rarely comes from UNHCR or its operational and implementing partners. In Kampala, there are organisations working with refugees which fall outside the tripartite agreement between the government, UNHCR and InterAid. The Finnish Refugee Council (FRC), International Rescue Committee, and Jesuit Refugee Service are operational partners (OPS) of UNHCR, running a variety of programmes for refugees in Kampala. Other INGOs which refugees mentioned were the Windle Trust Uganda (WTU), which provides several scholarship opportunities each year to refugees from the settlements to attend urban universities. Lutheran World Federation does some advocacy work and like WTU are funded by UNHCR, but not as implementing partners. FRC has been working in settlements and camps since 2004, but it only opened an office in Kampala in 2009, offering training in English and Business. In 2018 it coordinated and implemented projects across Kampala under the areas of Youth, Business (Livelihoods), Literacy, Capacity Building for Refugee-led Organisations, and Psychosocial Care. Other international NGOs like Oxfam have been working actively to promote a greater voice for RLOs within Kampala but without the resources to offer direct funding.

\section{Funding Streams}

Whilst our research identified over thirty registered RLOs in Kampala, of these, only two appear to have been funded by UNHCR: Young Africans for Integral Development (YARID) and One Youth One Heart $(1 \mathrm{Y} 1 \mathrm{H})$. In both cases, that funding has come from the Youth Initiative Fund coordinated as a one-off competition by UNHCR Headquarters in Geneva. Such opportunities are very much the exception. However, even when this funding has been awarded, the money has not always been forthcoming. For example, YARID's award was for a 'Soccer for Peace' programme in 2016. The funding that YARID won through the UNHCR Youth Initiative Fund competition was contested by UNHCR Uganda, who pointed out, following UNHCR Headquarters' decision to award, that YARID was not an implementing partner of UNHCR and therefore should not be permitted to receive the agreed funding. YARID's Director explained:

It was impossible to get the money. We spent 6-months arguing how the money would be spent. Eventually we got it in November, and they told us we had to spend it by December! Geneva controlled the money and was saying to UNHCR in Kampala 'we don't care if you give them the money'. I even told the Senior Programme Officer I was no longer interested, and she said they would send it to Interaid. Eventually, it was channelled through Windle Trust International. They wanted to charge administration costs but UNHCR stopped them. We had to do the project in just 6 weeks. The next year they said they would do the same funding. But UNHCR requested lots of documents. First, we signed a tripartite agreement. And then they said it was not valid. Then we signed a new agreement. Then they said it would not work because we needed to be a UNHCR Implementing Partner. But we are not able to become an IP.

\section{Formality and Legitimacy}


Indeed, within Kampala, the general view of UNHCR staff is that in order to receive UNHCR funding, an organisation must have the status of 'implementing partner' (IPs) - but they also acknowledge that RLOs are unlikely to meet the requirements to become an IP. One UNHCR staff member, working in the protection unit in community-based protection explained, 'Sometimes we support refugee organisations in events,' one of them explained, 'generally this is in-kind, like helping with tents or chairs... I actually don't know of other refugee CBOs [besides YARID] who received money from UNHCR in the last year.' But another colleague from the same unit did not think it realistic for refugee-led organisations to become UNHCR implementing or operational partners: 'They are too small and sometimes they disappear...It would be hard for UNHCR.'

In 2015 UNHCR Uganda published a call for expressions of interest for partnership with organisations to collaborate in the implementation of UNHCR assistance projects across Uganda, including in Kampala. ${ }^{1}$ This call was welcomed by many refugees as a chance to dismantle the supremacy of InterAid. One refugee leader in Kampala wrote to UNHCR about this directly, stating: 'It is encouraging that UNHCR is making a public call for partnership after working with only one partner in Kampala for over a decade. I believe it's going to play a big role in improving the services delivered to refugees in Uganda.' The letter went on to highlight UNHCR's exclusion of refugee-led organisations:

...Under the current guidelines, refugee-run organisations do not have the possibility to become implementing partners of UNHCR. I believe this needs to change, as refugees are in a unique position to support each other - if resources are available. The Uganda Refugee Policy gives refugees the right to work, freedom of movement and the right to organize themselves in associations or organisations but it seems that they are not enjoying fully that opportunity because of lack of support and resources from big Organizations include UNHCR. Today the bottom up approach is recommended to make sure affected communities are involved in all stages of the assistance and integration process to make sure they become responsible of their own destiny. This includes collaborating and partnering with refugee-run organisations. I would like here to inform you that refugee run-organizations exist in Kampala and I believe they have the potential to be implementing partners of UNHCR in different areas...Therefore, I request for refugee run-organizations to also be considered in this call of partnership and suggest a meeting with leaders of refugee run-organizations to discuss this possibility further.

This letter to UNHCR went unanswered, and later in the year InterAid was announced as the continuing - and sole - UNHCR implementing partner in Kampala. ${ }^{2}$

\section{Competition over Resources}

\footnotetext{
${ }^{1}$ For full call, see: http://web.monitor.co.ug/Tenders/2015/06/16/unhcr-partners23062015.pdf

2 Our own requests for meetings with UNHCR Uganda or InterAid with refugee-led organisations during our research were met with either silence or disinterest.
} 
It is unsurprising that RLOs expressed reluctance towards 'partnering' with InterAid. Many refugees we spoke with expressed a feeling that effective, active RLOs were overlooked for funding when there were opportunities for partnership in project implementation to which funding was attached. This was primarily attributed to InterAid's fear of competition. InterAid was perceived to prefer to partner with organisations which they could direct and control. One refugee offered a perspective on Interaid:

What Interaid does is fight refugee-led organisations because they see us as competition. UNHCR is working with 4 local organisations and they are all national organisations. In Kampala it is just Interaid, and they have been the only urban IP for 25 years. The UN audit on the corruption scandal said one of the organisations was involved in corruption. It wasn't named but all the refugees know who it was.

One CBO in Kampala which InterAid partnered with and appeared to provide for financially was Refugee Now, which described itself as a platform for urban refugees to improve their lives. However, other refugees alleged that it was run by InterAid staff, with refugees included only as tokenistic evidence of InterAid's 'community' basis. Overall, refugees did not speak highly of the existing opportunities they saw for engaging with refugee-serving institutions in Kampala.

\section{Predetermined 'Opportunities' for RLOs}

The experiences of the RLO URISE illustrate the frustrations refugees feel towards the opportunities for engagement that InterAid present. A youth group led by a charismatic young Congolese refugee called Felicity, URISE had formed in 2017 when its members met through participating in music, dance and drama (MDD) groups put together by InterAid. Their objective was to foster the talents and ambitions of young people and expand opportunities for them. InterAid had groups that did MDD, but URISE wanted to move beyond that to train other young people in the community in these areas, which included creative pursuits like music, art, and design, but also computer programming and business. In turn, they envisioned that young people would be able to make money through the skills they developed.

URISE members were involved in other activities to make money to support their 'showcasing' activities. Many of them had received skills training from INGOs in Kampala, including Kampabits and the Butterfly Foundation, which did not specifically target refugees, offering assistance to disadvantaged young people in general. These skills in art, graphic design, and computer programming were what they hoped to be able to teach to other young people. After painting murals at the Antonio Guterres Urban Refugee Centre at Kabusu, which URISE had hoped would show InterAid what they were capable of, Felicity had heard that InterAid was looking for someone to manufacture paraphernalia for their Youth Solidarity Summit. URISE bought a printing press and used it to make sample t-shirts, mugs and badges. They took them to InterAid but InterAid, she said, chose a Ugandan youth group to design and produce the shirts for the summit. 'They were three days late delivering the items - they nearly missed the event,' Felicity told us. 'The lack of opportunities for refugees is a big 
challenge, especially for young people. But who should you go to when the person to whom you are reporting your challenges is the same person stopping you?'

\section{Refugee-led Alternatives}

But some RLOs in Kampala which have been able to thrive have done so by engaging in alternatives to the enduring provider/beneficiary model. In 2016, four Congolese refugees who were running their own registered $\mathrm{CBO}$ s came together to discuss how they might bring refugee-led organisations in Kampala together to combat the institutional dominance of InterAid. Together they formed the Refugee Led Organisation Network (RELON). One of these founding members was Robert, who runs YARID. Through his professional and personal connections, Robert began reaching out to leaders of other refugee nationality communities with the aim of making the network more representative and inclusive. At an initial meeting of RELON, ultimately eleven representatives arrived - four Congolese, two Eritreans, four South Sudanese, and one Rwandan - all of whom had formed or were in the process of forming community organisations to assist some of the 80,000 refugees in the city. At its most recent count in January 2019 more than twenty-five organisations has joined. The interest taken in the network by refugees from a range of nationalities and backgrounds, indicates its value to those working with and for their communities.

Whilst we sat in his office before the meeting, Robert described the objectives of RELON. The first was practical; by coordinating the activities of refugee-led $\mathrm{CBO}$, there were opportunities for mutual learning and improved access to funding opportunities could be achieved. The second motivation was legitimacy and the possibility for influential advocacy that a show of unity might generate. RELON provided a means for refugees in Kampala to 'speak with one voice', in Robert's words, on the issues affecting them. This choice of language was in itself significant; it implied that someone is there to listen. The coordination and capacity building of the network and the show of unity it could enable were integral to the third objective: for refugee initiatives to have the choice not to partner with national NGOs, and thereby 'avoid corruption at certain organisations.'

Despite the existence of RELON, official recognition of it by formal institutions remained limited. In November 2018, RELON launched as a network for Kampala's RLOs, with over 20 organisations represented. Neither Interaid nor UNHCR accepted the invitation to participate in the launch. Only the Office of the Prime Minister sent a representative, despite invitations having been sent to numerous community support workers at both UNHCR and InterAid. At the launch of RELON, refugee representatives were sternly reminded by the OPM representative in attendance that their role was to 'stick to non-political activities, conform, and do genuine work to promote peaceful coexistence.' 'We face a lot of bureaucracy and censorship here' explained Augustin of Youth Action Empowerment Initiative, a South Sudanese organisation which he registered in 2015. 'Our services are reduced to advocacy and we cannot do anything. transformative. We are limited by this system.'

The emergence of RELON in Kampala - and the objectives that drove its expansion - spoke to the changing environment for civil society and the growing formalisation of refugee-led social 
protection in the city. Yet refugees still work within an environment where funding is scarce and opportunities for institutional engagement are limited, with InterAid retaining control over which organisations become 'visible' to UNHCR. Such a context makes initiatives like RELON even more important for the opportunity it presents to enable RLOs to have a national platform to collectively mobilise and reach beyond Uganda for opportunities.

For other refugees, contending with the frustrating monopolisation of refugee assistance by InterAid has led to antagonism and activism. Refugee dissent has gathered pace in recent years despite the pressures refugees face to remain apolitical. In 2018, a corruption scandal indicted staff at the Office of the Prime Minister, with allegations made by refugees about mismanagement of government resources amongst other issues ${ }^{3}$. An online message sent by one refugee activist to a refugee network in Kampala detailed a survey he had undertaken on issues refugees want raised and the names of specific officers who refugees would like dismissed for corruption - at InterAid, UNHCR, and the Office of the Prime Minister, on the basis that:

As the investigations into refugee scandals [over inflated numbers] continue, if you move around and ask questions to refugees privately they will tell you what they know and who abused them...they will also tell you to speak quietly because the names are for big people...in most cases some [refugees] will tell that is a sign of disrespect to mention the names of a big person or authority... [but] this is an opportunity for you to contribute for the better future of refugees here in Uganda. On what do you think investigations should focus and which officers do you think have abused refugees and you would like him or her out? 4

The Congolese activist leading this assertive call to action, Pecos, was the founder of a CBO in Kampala (called PDDR), which he has since left to start another organisation (called Foundation PPDHR). Having left the Democratic Republic of Congo as a political refugee, he has since committed to human rights activism in Uganda. 'Kampala is a hub for recruitment by armed groups in DRC. I wanted to make an organisation which would intervene in this problem, but it was too political and my fellow refugees objected. UNHCR told me that I only had two options if I wanted to stay here in Kampala - be a human rights defender, or keep quiet and wait for resettlement. I chose to defend human rights, but whenever I speak up, I risk being arrested', Pecos explained.

Yet Pecos is viewed with ambivalence by the leaders of other refugee-led organisations. He is seen by many as a much-needed whistle-blower, but his unpredictability and his sometimes hostile comments, for example about LGBT issues, means he is equally perceived as a potentially destructive force for advocacy work that organisations are doing to promote their inclusion in more formal assistance efforts. In 2017, he was ousted by the other staff of his original organisation. This example illustrates that many RLO leaders are aware of the need to

\footnotetext{
${ }^{3}$ Refugee Scandal: OPM suspends 4 officials. February 6, 2018. https://www.monitor.co.ug/News/National/Refugee-scandal--OPM-suspends-4-officials/6883344293038-mtpxyx/index.html

${ }^{4}$ Refugee activist, WhatsApp message to refugee-led network, May 8, 2018.
} 
self-regulate the behaviour of other RLOs in order to safeguard their collective reputation. They are especially concerned that in critiquing InterAid and UNHCR, they are not perceived as a liability by formal humanitarian and development actors, and can still access alternative funding opportunities.

These alternative forms of refugee-led assistance have been especially visible in Kampala during Covid-19. In Kampala, for example, in April 2020, many refugees faced severe food shortages because of the lockdown as the government publicly announced on national television that "refugees should be in the camps" and that "non-nationals will not get food aid" except in refugee camps. Again, refugee-led organisations filled key gaps.

Hope for Children and Women Victims of Violence (HOCW), for example, founded by Congolese refugee Bolingo Ntahira ordinarily supports around 1,300 refugees a year through vocational training, psychosocial support and English lessons. During the Covid-19 lockdown, it distributed food and soap to refugees and Ugandans in the Ndejje area of Kampala, with hundreds of beneficiaries. Similarly, YARID distributed baskets of flour, soap, beans, sugar, and cooking oil to the most vulnerable in the community. It identified recipients through community networks, and delivered food on bodaboda (motorcycle taxi) where needed, and reached hundreds of households. Initially, these RLOs mainly depended upon financial contributions from within the community or crowd-funding opportunities. The Open Society Foundations have emerged as among very few funders willing to fund the work of RLOs in Kampala and across East Africa (Betts, Easton-Calabria, and Pincock 2020).

\section{Discussion}

UNHCR Uganda's approach to refugee-led organisations can be understood as a continuation of its ongoing 'provider/beneficiary' model, with RLOs falling under the mandate outlined in the 'community-based protection approach' it claims to take (UNHCR 2013: 6). Refugees' participation under this approach positions them ultimately as beneficiaries, rather than engaged through meaningful delegation of responsibilities or supported to orchestrate their own ideas. The refugees we spoke with were keenly aware of this dynamic, sharing experiences of countless 'sensitisation trainings' in areas such as health and gender-based violence to which community leaders tend to be invited. Yet these trainings were not followed up with the provision of material or equipment to act upon their presumed 'newly acquired' knowledge. Any funding for such activities allocated on paper, according to refugees, was rarely actually received.

An organisational culture such as this, in which there is no institutional support for activities, let alone capacity building, sidelines RLOs and keeps them from engaging even as minor actors in localisation. To refugees, this is not accidental; it is seen as a deliberate strategy for retaining the status quo in Kampala. To the leaders of RLOs, UNHCR also appears remote and detached from the communities it purports to assist. One explained, 'Of course, I understand the challenges they have with the government. The government is on top. UNHCR cannot work at all without the government...I have tried to get a meeting with the UNHCR 
Representative since he came here. I have written at least 3 times but never had a response...We never see anyone on the ground except for the community services people, and they are basically the same as InterAid'.

Refugee-led organisations that emerge to fill gaps in services find themselves in a delicate situation; able to legally register and run, but having to operate in ways that did not disturb the existing official or organisational balance of power. To some extent, keeping InterAid, OPM and UNHCR on board matters; especially for those who do not have access to international contacts in humanitarian and development organisations, InterAid and UNHCR often appear to be the only means of solidifying community-based activities into something sustainable, due to their monopoly over official refugee provision in the city. Whilst some refugees are seeking ways to mobilise collectively through RELON, this initiative still relies on having stronger members who have the networks necessary to be able to access opportunities.

Yet whilst the most established $\mathrm{CBO}$ s such as $\mathrm{HOCW}$ and YARID are often perceived by other organisations to have been successful because of funding from UNHCR, our research indicates that this is not really the case. It is reaching beyond the borders of Uganda that enables the greatest growth for refugee-led organisations. Robert's recounting of successfully bidding for funding from UNHCR's Global Youth Initiative Fund provides more background to the UNHCR officers we spoke with who provided this as an example of the agency's successful work with refugee-led organisations. According to Robert, although YARID was told they would receive the funding, the money was initially not being released by UNHCR Uganda because YARID was not a UNHCR implementing partner. It was only through his contacts at UNHCR Geneva that Robert was able to bypass UNHCR Uganda to access the money. As a result of these delays, the success of the project was compromised, as was faith in UNHCR's legitimacy at the national level.

For organisations like YARID and HOCW, keeping refugee governance institutions in Uganda on side is the safest bet - but this requires finding other means of generating income. 'If you wait for just ten thousand dollars funding, you'll be waiting forever, and spend that money in a year going to the office and doing what they ask but it'll never come back to you,' Robert stated. For both YARID and HOCW, international connections had been vital for enabling this strategy. For organisations which cannot directly reach either informal international supporters who might advocate for them or formal humanitarian and development actors, membership of RELON is only one option. Some organisations now aim to develop themselves as social enterprises rather than rely on partnerships at all. This was a perspective repeated by Joseph, the vice-chair of RELON and the organisation Hope for Refugees in Action, which focuses on microfinance and credit for refugees to start businesses. 'Depending on donor money is unsustainable for refugee-led organisations,' he explained. 'There is sometimes money for capacity building, but that is all.'

Despite its obvious implications for sustainability, when there are no clear routes for engagement and partnership, personal relationships matter even more. Several of the most successful RLOs have cultivated these in order to access funding. Yet this model is deeply 
problematic for the ways that it risks exacerbating inequalities within refugee communities. Refugees who have been able to obtain support for their activities in Kampala are almost all male, with a certain level of education and ability to speak English. They are also those who have worked with international organisations and thus understand the expectations that supporters will have for the relationship, as well as what activities will be seen as worthwhile causes. In Kampala, RLO leaders who have had fewer opportunities to make connections or are simply unable to communicate and frame their activities in particular ways that appeal to external supporters, find it harder to access support. Refugees in Kampala also felt that these limited options for funding leads to the replication of programmes of activities which are seen as successful in getting external donor attention - rather than being those which are most effective in meeting the needs of their communities.

At an international level, there is growing acknowledgement of the role that RLOs might play within the formal humanitarian system. Yet refugee-led initiatives are generally locked out of formal funding mechanisms and access to elite policy networks. Whilst rhetoric at the global level suggests localisation has become a major theme in elite policy circle, this has failed to unfold at at the local level in Kampala. Partly, this is an issue of policy. Formal humanitarian and development actors play a key role in constraining and enabling refugee-led social protection, but without a clear global policy framework on how to engage refugee-led organisations, within UNHCR or elsewhere, national UN representations have discretion in how they engage refugee-led social protection. In Kampala, InterAid is the only implementing partner. This reflects one of UNHCR's dominant priorities: to retain a good relationship with national host governments, in this case one that favours InterAid and limits refugees' political mobilisation.

Whilst the 'localisation' agenda does not explicitly call for RLOs to be brought into refugee response strategies, we suggest that this is largely due to the ways that the immensely important work of RLOs is obscured by a top-down perspective on refugee governance. Systemically mapping the work of RLOs is thus imperative. This paper has highlighted the role that refugees play in social protection and assistance in Kampala, where as shown, UNHCR remains unaware of the vast majority of refugee-led activities; yet this is in a country heavily associated within global policy discourse with refugee self-reliance. Elsewhere, RLOs are also likely to face challenges around visibility and participation.

This paper has also emphasized the need to address the various barriers RLOs face in expanding their impact. It is clear from the successful cases observed here that many RLOs have the potential to fill important niches in key areas. Recognizing RLOs as 'civil society actors' under the Global Compact's workstream on localisation may provide a starting point for donors which seek to work with refugees more directly. Commitments made by donors and aid organizations to provide 25 per cent of global humanitarian funding to local and national responders 'as directly as possible' by 2020 in the Global Compact's Grand Bargain offer an opportunity to direct more funding towards, and better integrate, RLOs (UN 2018). RLOs may present a risk, but piloting initiatives in which RLOs are funded directly is likely to be much more cost-effective than allocating resources through multi-layered processes of delegation via UNHCR and its implementing partners. This is not a new approach, but the 
opportunities currently are few and far between, and often available only to organisations which meet certain criteria.

\section{Conclusion}

Refugee-led organisations are important and neglected providers of social protection in Kampala, where they fill gaps left by formal humanitarian and development actors in areas as diverse as education, vocational training, psychosocial support, health, microfinance, sport, youth engagement, and legal representation. However, they face a chicken-and-egg problem of not having the funding or recognition to build capacity but not having the capacity to acquire funding or recognition. Some organisations succeed in spite of structural constraints. There is, we show, a common pattern underlying the emergence of these outliers: they bypass the formal humanitarian system by building their own transnational networks.

Yet as this article shows, this leads to some RLOs being able to grow and expand their activities, while others remain marginal, for reasons that are sometimes related to their exclusion from hierarchical structures of humanitarian governance rather than the substantive ability to respond to community needs. Despite the promise of the localisation agenda within global-level debates on humanitarian and refugee governance, the practice of globalization is highly politicised and contested on the ground. Drawing upon the 'critical localism' literature offers a particularly useful means to critically engage with the localisation agenda within both policy and academic literature (MacGinty 2015; MacGinty and Richmond 2013). Understanding how localisation works in practice - and the gap between localisation rhetoric and reality - relies upon moving beyond a dualistic view of the 'global' and the 'local', and instead recognizing the role of interests and power relations that shape governance authority within particular contexts.

The context of Covid-19 has offered a new opportunity to recognise to create more participatory forms of humanitarian governance. During lockdown measures, RLOs such as those in Kampala, stepped into the vacuum left by inadequate national and international assistance. This triggered an unprecedented focus on the work of RLOs, within the media and policy circles. However, despite a renewed willingness by international organisations, NGOs, and foundations to explore concrete mechanisms to support RLOs, donor governments remain hesitant to directly fund RLOs, mainly due to issues such as risk, accountability, and lack of evidence on effectiveness.

Our analysis shows that the translation of localisation from rhetoric to reality cannot be taken for granted. Localisation is a contested concept with no agreed upon policy definition, even in the humanitarian context. Within refugee governance, despite the aspiration to include "local actors', there is no clear and consistent policy guidance. This ambiguity is both a reflection of political contestation and a catalyst for contestation within particular contexts such as Kampala. UN agencies, international NGOs, the national government, and refugee leaders all have specific interests and agendas that have shaped the selective inclusion and exclusion of RLOs within refugee governance. The inclusion and relative success of particular RLOs owes more to either their instrumental value to international actors and national actors, or to their 
ability to strategically bypass formal humanitarian governance, than their inherent value to the community.

From an academic perspective, the implication is that we have to go beyond the descriptive and the normative to understand the politics of localisation. Meanwhile, for those people who wish to improve the legitimacy and effectiveness of humanitarian governance, the challenge is about more than just 'bringing refugees in' to the localisation agenda; it is about understanding the interests and power relations that underlie inclusion, exclusion, and delegation.

\section{Acknowledgements}

The authors would like to thank Robert Hakiza, founder of Young Africans for Integral Development (YARID), and Bolingo Ntahira, founder of Hope of Children and Women Victims of Violence (HOCW) for their contribution to this research, as well as all of our other informants.

\section{Declaration of interest statement}

The authors confirm there is no conflict of interest.

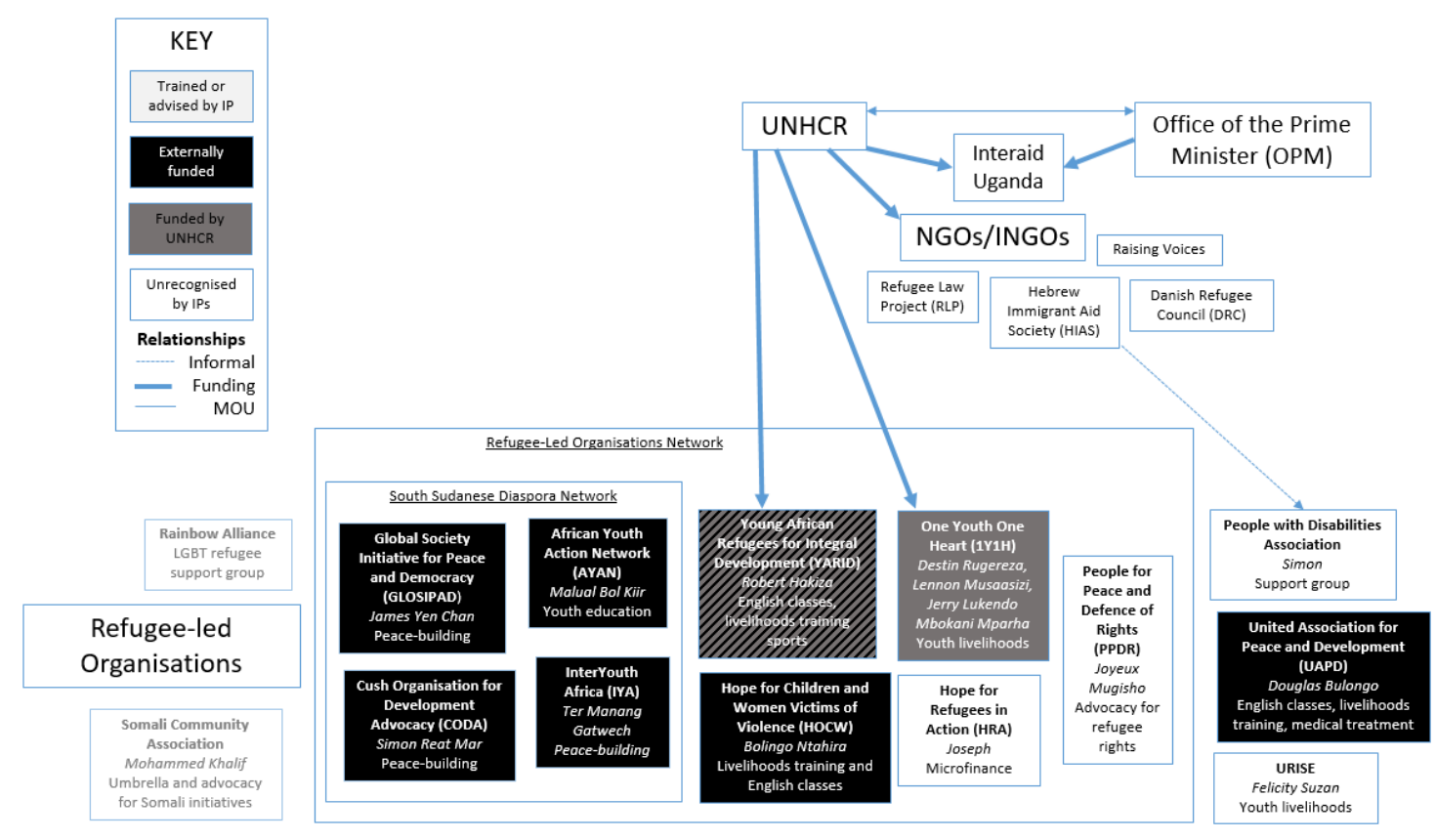

Figure 1: Refugee-led, national, and international organisations in Kampala

\section{Bibliography}


Acharya, A. (2004). How Ideas Spread: Whose Norms Matter? Norm Localisation and Institutional Change in Asian Regionalism. International Organization, 58(2), 239-275.

Acharya, A. (2009). Whose ideas matter? Agency and Power in Asian Regionalism. Ithaca NY: Cornell University Press.

Autesserre, S., (2010). The Trouble with the Congo: Local Violence And The Failure of International Peacebuilding (Cambridge Studies in International Relations). Cambridge: Cambridge University Press.

Baines, E. and Paddon, E. (2012). "'This Is How We Survived': Civilian Agency and Humanitarian Protection," Security Dialogue 43.3: 231-247.

Barbelet, V. (2018) As local as possible, as international as necessary: understanding capacity and complementarity in humanitarian action. Report. London: Overseas Development Institute.

Barrientos, A., and Hulme, D. (2009). Social protection for the poor and poorest in developing countries: reflections on a quiet revolution: commentary. Oxford Development Studies, 37(4).: 439-456.

Bennet, C. (2016). Time to Let Go. Remaking humanitarian action for the modern era. London, ODI.

Betts, A., Easton-Calabria, E., \& Pincock, K. (2020), 'Why Refugees Are Assets in the Fight Against Coronavirus', The Conversation, 28 April, https://theconversation.com/why-refugeesare-an-asset-in-the-fight-against-coronavirus-136099

Betts, A. \& Orchard, P. (2014). Implementation and World Politics: How International Norms Change Practice. Oxford: Oxford University Press.

Betts, A. and Jones, W. (2016). Mobilising the Diaspora: How refugees challenge authoritarianism. Cambridge: Cambridge University Press.

Betts, A., Chaara, I., Omata, N., \& Sterck, O. (2019).. Refugee economies in Uganda: What difference does the self-reliance model make?. Refugee Studies Centre, University of Oxford. Betts, A.; Bloom, L.; Omata, N. (2016). Refugee Economies. Oxford University Press.

Bloch, A. (2008). Refugees in the UK labour market: The conflict between economic integration and policy-led labour market restriction. Journal of Social Policy, 37(01).: 21-36.

Bradley, M.; Milner, J.; and Peruniak, B. (Eds). (2019). Refugees' Roles in Resolving Displacement and Building Peace: Beyond Beneficiaries. Georgetown University Press. 
Carrier, N. C. (2016). Little Mogadishu: Eastleigh, Nairobi's Global Somali Hub. Oxford University Press.

Chambers, R. (1986). Hidden losers? The impact of rural refugees and refugee programs on poorer hosts. International migration review, 20(2)., 245-263.

Chambers, R. (1997). Whose Reality Counts? Putting the First Last. London: Intermediate Technology Publications.

Cleaver, F. (1999). Paradoxes of participation: questioning participatory approaches to development. Journal of International Development. 4(11) 597-612.

Cloward, K. (2014). False Commitments: Local Misrepresentation and the International Norms Against Female Genital Mutilation and Early Marriage. International Organization, 68(3), 495526.

Cloward, K. (2016). When Norms Collide. New York: Oxford University Press.

Devereux, S., \& Sabates-Wheeler, R. (2004).. Transformative social protection. IDS Working Paper 232, Institute of Development Studies, University of Sussex.

Escobar, A., (2011). Encountering Development, The Making and Unmaking of the Third World. Princeton, New Jersey: Princeton University Press.

Ferguson, J. (1990). The Anti-Politics Machine: "Development," Depoliticization and Bureaucratic Power in Lesotho. Cambridge: Cambridge University Press.

Fiddian-Qasmiyeh, E. (2015).. South-South Educational Migration, Humanitarianism and Development: Views from the Caribbean, North Africa and the Middle East. Routledge.

Gold, S. J. (1992). Refugee Communities: a comparative field study. London: Sage.

Grabska, K. (2006). Marginalization in urban spaces of the global south: Urban refugees in Cairo. Journal of Refugee Studies, 19(3)., 287-307.

Grand Bargain (2016). A shared commitment to better serve people in need. Full text available at:

https://reliefweb.int/sites/reliefweb.int/files/resources/Grand Bargain final $22 \mathrm{M}$ ay FINAL-2.pdf

Griffiths, D., Sigona, N., \& Zetter, R. (2006). Integrative paradigms, marginal reality: refugee community organisations and dispersal in Britain. Journal of Ethnic and Migration Studies, 32(5)., 881-898. 
Hammond, L. (2004). This place will become home: refugee repatriation to Ethiopia. Cornell University Press.

Harrell-Bond, B.E. (1986). Imposing aid: emergency assistance to refugees. Oxford: Oxford University Press.

Horst, C. (2008). The transnational political engagements of refugees: Remittance sending practices amongst Somalis in Norway. Conflict, Security \& Development, 8(3).: 317-339.

Horst, C. (2019). Refugees, peacebuilding, and the anthropology of the good. Refugees' Roles in Resolving Displacement and Building Peace: Beyond Beneficiaries, 39.

IFRC (2018) World Disasters Report 2018: Leaving No One Behind. Report. Geneva: IFRC. Jacobsen, K. (2005). The economic life of refugees. Kumarian Press.

Jose, B., \& Medie, P. A. (2015). Understanding why and how civilians resort to self-protection in armed conflict. International Studies Review, 17(4)., 515-535.

Kibreab, G. (1987). Refugees and development in Africa: The case of Eritrea. The Red Sea Press. Krause, U. (2014). Analysis of empowerment of refugee women in camps and settlements. Journal of internal displacement, 4(1)., 28-52.

Lischer, R., (2005). The end of words: the language of reconciliation in a culture of violence. Grand Rapids, Mich; Cambridge: Eerdmans.

MacGinty, R. \& Richmond, O. (2013). The Local Turn in Peace Building: a critical agenda for peace. Third World Quarterly, 34:5, 763-783

MacGinty, R. (2015). "Where is the Local? Critical Localism and Peacebuilding." Third World Quarterly 36(5) 840-856.

Masullo, J., Mouly, C., \& Garrido, M. B. (2019). Alternative Forms of Civilian Noncooperation with Armed Groups: The Case of Samaniego in Colombia. In Civil Resistance and Violent Conflict in Latin America (pp. 111-136).. Palgrave Macmillan, Cham.

Maystadt, J. F., \& Verwimp, P. (2009). Winners and losers among a refugee-hosting population (No. UCL-Université Catholique de Louvain). CORE.

Milner, J. (2009). Refugees and the regional dynamics of peacebuilding. Refugee Survey Quarterly, 28(1)., 13-30.

Mylonas, H. \& Shelef, N., (2017). Methodological challenges in the study of stateless nationalist territorial claims. Territory, Politics, Governance., 5(2), pp. 145-157. 
Parker, B. (2016). What Does Localisation of Humanitarian Aid Mean in Practice? Interview with Ben Parker at AidEx, Brussels. YouTube video.

Phillimore, J. (2012). Implementing integration in the UK: Lessons for integration theory, policy and practice. Policy \& Politics, 40(4).: 525-545.

Pincock, K., Betts, A. \& Easton-Calabria, E. (2020). The Global Governed: Refugees as providers of social protection and assistance. Cambridge: Cambridge University Press.

Purkey, A. (2019). Transformative Justice and legal conscientization. Refugees' Roles in Resolving Displacement and Building Peace: Beyond Beneficiaries, 75.

Roepstorff, K. (2020). A call for critical reflection on the localisation agenda in humanitarian action. Third World Quarterly, 41:2, 284-301

Ruiz, I., \& Vargas-Silva, C. (2015). The labour market consequences of hosting refugees. Journal of Economic Geography, 16(3)., 667-694.

Rwakaringi, M. D. (2017) Is Uganda the World's Best Place to be a Refugee? Newspaper report. Guardian Africa Network: Guardian. Available at: https://www.theguardian.com/world/2017/apr/01/is-uganda-worlds-best-place-forrefugees-south-sudan Accessed 5th March 2020.

Salehyan, I., (2010). Transnational insurgencies and the escalation of regional conflict: lessons for Iraq and Afghanistan. Carlisle, PA: Strategic Studies Institute, U.S. Army War College.

Scott, J. C., (1998). Seeing like a state: how certain schemes to improve the human condition have failed. New Haven; London: Yale University Press.

Suhrke, A. (1998). Burden-sharing during refugee emergencies: The logic of collective versus national action. Journal of refugee studies, 11(4)., 396-415.

UN (2018). Global Compact on Refugees. Geneva: United Nations.

UNHCR (2013). UNHCR Community-Based Protection Policy. Geneva: UNHCR.

UNHCR (2019). About Us. Webpage. Available at: https://www.unhcr.org/uk/about-us.html. (accessed September 1, 2019).

UNHCR (2020) Global Focus: Uganda. Webpage. Available at: http://reporting.unhcr.org/node/5129\# ga=2.42074533.182986234.15834211011595964279.1574778378 (accessed $5^{\text {th }}$ March 2020).

Van Brabant, K., \& Patel, S. (2017). Understanding the Localisation Debate. Global Mentoring Initiative. 
Werker, E. (2007). Refugee camp economies. Journal of Refugee Studies, 20(3).: 461-480.

Zetter, R. and Pearl, M. (2000). 'The minority within the minority: refugee community based organisations in the UK and the impact of restrictionism'. Journal of Ethnic and Migration Studies, 26(4).: 675-698.

Zetter, R., Griffiths, D. and Sigona, N. (2005). 'Social capital or social exclusion? The impact of asylum seeker dispersal on UK refugee community organisations'. Community Development Journal, 40 (2).: 169-81. 